\title{
A Complex Clinical Case of Recurrent Vaginitis
}

\author{
Alina V Solovyova* and Viola Gace \\ Department of Obstetrics and Gynecology, University of Russia (RUDN University), Russia
}

Submission: October 29, 2017; Published: January 08, 2018

*Corresponding author: Alina V Solovyova, Department of obstetrics and gynecology with the course of perinatology of the Peoples Friendship University of Russia (RUDN University), Moscow, Russian, Tel: +79854477928; Email: av_soloveva@mail.ru

\section{Annotation}

The article describes the case of a complex diagnosis of recurrent vaginal biotope disturbance in a 40 years old woman. The use of intravaginal drugs and systemic antibiotics had a short-term effect. Difficulties in diagnosing premature ovarian failure were associated with the presence of an intrauterine levonorgestrel-releasing system and amenorrhea.

Keywords: Recurrent vaginitis; Premature ovarian failure; Intrauterine levonorgestrel-releasing system; Amenorrhea

\section{Case Report}

Recurrent vaginitis are diseases of the lower part of the urogenital tract occurring at a frequency of 8-30\% 3-4 months after the treatment of the vaginal biotope disturbances [1,2]. Repeated episodes of the disease are associated with difficulties in finding the root causes of vaginal biocenosis disorders, selecting a treatment regimen, etc [1].

Patient S., 40 years old met the physician due to recurrent burning and itching of the external genital organs in the last 1.5 years. She noted sleep disturbance for 6 months and increased sweating at night. She was repeatedly examined and received treatment from doctors, were applied 7 types of intravaginal drugs and twice were prescribed antibiotics per os. She noted relief after treatment for 2-5 weeks and then persistent relapses of symptoms from the external genitalia [2].

Anamnesis: normal menstrual function, 2 pregnancies, 2 childbirthon time.

\section{Contraception: condoms.}

At age of 38 she was hospitalized with abnormal uterine bleeding. Was performed curettage of the uterus and histological examination showed simple glandular hyperplasia.

At the request of the patient, an intrauterine levonorgestrel releasing system was introduced. Notes amenorrhea for 1.5 years.

Somatic anamnesis unremarkable. No allergies. No injuries.

She was repeatedly examined: blood tests, liver function, fasting glucose, all value were within the limitsrate. In the urinalysis three times were detected E. coli in a titer of $106 \mathrm{cfu} /$ ml. 5 times STI were performed and only in one of them was detected U. Urealiticum in a titer that exceeded normal parameters. The patient received antibacterial therapy and noted improvement. Smears of vaginal contents (4 strokes): were as below: leukocytes from 2-4 to 30-40 ina line of sight, flora consisted in little amount of bacilli and cocci. Trichomonas and gonococci were not found.

Objectively: height $162 \mathrm{~cm}$, weight $57 \mathrm{~kg}$. Skin of physiological color. Defecation is regular. Urination is frequent and painless.

Gynecological examination: the external genital organs are formed correctly, the hair is of female type. Mucous of the vagina and cervix uterus is hyperemic and swollen, mild mucous discharge.

Smear of vaginal discharge: leukocytes 25-35 in the line of sight, detected flora: cocci completely, gonococci and trichomonas are not found, fungi of the genus Candida. Epithelium 15-20-25 in the line of sight.

PCR of vaginal discharge in real time in quantitative way consisted in 103CFU lactobacillus, 105-107 Streptococcus spp. and 105 Candida spp.

Hormones level: FSH 47MED/ml, prolactin, TTH - norm, estradiol - 70pmol/l (below the norm).

Ultrasound of pelvic organs: No follicles visualized, changed ovaries volume of the ovaries which corresponds to reproductive age.

Diagnosis: N 76.0 Acute vaginitis. B 37.3+Candidiasis of the vulva and vagina. E28.3. Primary ovarian failure. 
Recurrent impairment of the vaginal biocenosis was associated with premature ovarian failure and decrease in estrogen (estradiol) in the blood. The diagnosis of premature ovarian failure was manifested by sleep disturbance and sweating at night. Amenorrhoea, which arose on the background of the intrauterine levonorgestrel-releasing system, did not allow the evaluation of the patient's menstrual function and its diagnosing on time.

\section{References}

1. Federal clinical recommendations on the management of bacterial vaginosis (2015).

2. Management of Vaginal Discharge in Non-Genitourinary Medicine Settings: C linical Effectiveness Unit February 2012.

Your next submission with Juniper Publishers will reach you the below assets

- Quality Editorial service

- Swift Peer Review

- Reprints availability

- E-prints Service

- Manuscript Podcast for convenient understanding

- Global attainment for your research

- Manuscript accessibility in different formats

( Pdf, E-pub, Full Text, Audio)

- Unceasing customer service

Track the below URL for one-step submission https://juniperpublishers.com/online-submission.php 